\title{
Molecular characterization of extensively drug resistant (XDR), extended spectrum beta-lactamases (ESBL) and New Delhi Metallo beta-lactamase-1 (blaNDM1) producing Escherichia coli isolated from a male dog - a case report
}

\author{
Bommenahalli S. Pruthvishree ${ }^{1 \#}$, Obli R. Vinodh Kumar ${ }^{1 \# *}$, \\ Mani Sivakumar ${ }^{2}$, Shikha Tamta ${ }^{1}$, Ramanjeneya Sunitha ${ }^{2}$, \\ Dharmendra K. Sinha ${ }^{1}$, and Bhoj R. Singh ${ }^{1}$ \\ ${ }^{1}$ Division of Epidemiology, ICAR-Indian Veterinary Research Institute, Izatnagar, Bareilly, \\ Uttar Pradesh, India \\ ${ }^{2}$ Division of Veterinary Public Health, ICAR-Indian Veterinary Research Institute, Izatnagar, Bareilly, \\ Uttar Pradesh, India
}

PRUTHVISHREE, B. S., O. R. VINODH KUMAR, M. SIVAKUMAR, S. TAMTA, R. SUNITHA, D. K. SINHA, B. R. SINGH: Molecular characterization of extensively drug resistant (XDR), extended spectrum beta-lactamases (ESBL) and New Delhi Metallo beta-lactamase-1 (blaNDM1) producing Escherichia coli isolated from a male dog - a case report. Vet. arhiv 88, 139-148, 2018.

ABSTRACT

In this article, we report the molecular characterization of extensively drug resistant (XDR), extended spectrum, class $\mathrm{C}$ beta-lactamases and NDM-1 carbapenemase producing E. coli, isolated from the scrotal fluid of a 3-year-old male dog. In an antibiotic susceptibility test the $E$. coli isolate was susceptible only to tigecycline and resistant to all clinically applicable antibiotics tested in the study. The minimum inhibitory concentration (MIC) of meropenem, cefotaxime and cefepime was 256, 128 and $64 \mu \mathrm{g} / \mathrm{mL}$, respectively. On genotypic screening by PCR, the isolate was positive for blaNDM, blaCTX-M, blaAmpC, blaTEM and sull genes. The isolate was a ESBL, AmpC and metalo beta-lactamase producer. On molecular pathotyping, the isolate harbored the Shiga toxin producing gene (St $x 2)$. The extensively drug resistant, carbapenem resistant and ESBL producing $E$. coli constitutes a major public health concern, since there is a great chance of dissemination of resistance genes to humans due to the close association of humans and companion animals. To the best of our knowledge, this is the first report of blaNDM1 isolated from a dog in India.

Key words: dog; NDM; ESBL; carbapenemase; beta-lactamase

\footnotetext{
*Corresponding author:
}

Vinodh Kumar, O. R, Scientist, Division of Epidemiology, Indian Veterinary Research Institute, Izatnagar, Bareilly, Uttar Pradesh 243 122, India, Phone: +91 8859784 853; E-mail: vinodhkumar.rajendran@gmail.com

\#Both authors contributed equally to the manuscript

ISSN 0372-5480

Printed in Croatia 
B. S. Pruthvishree et al.: Molecular characterization of extensively drug resistant (XDR) Escherichia coli isolated from a male dog

\section{Introduction}

Nowadays keeping companion animals, especially dogs and cats, is gaining popularity due to the changes in lifestyle of human beings and also the growing attention given to pet care. As a result of increased pet care, antimicrobial agents are commonly used in companion animal practice, often including antimicrobial preparations used in human medicine. At present, antimicrobial drug resistance is a problem all over the world. The blanket use of antimicrobials has led to the emergence and spread of antimicrobial drug resistance in microbes, including pathogens, leading to imbalance in the microbiota of our systems and environment. The occurrence of antimicrobial resistant strains in food producing and companion animals is increasing and leading to alarm that the cross species spread of these resistant bacteria could be of great public health significance (STOLLE et al., 2013; GHATAK et al., 2013; PRUTHVISHREE et al., 2017). The term "extensive drug resistance" (XDR) is used to signify gram negative bacteria resistant to all potentially effective antibiotics, except one to two antibiotics left as treatment options (FALAGAS and KARAGEORGOPOULOS, 2008). The antibacterial resistant bacteria harboring virulence markers are hazardous, since they cause infections which are difficult to treat. Shiga toxin (SETC) producing E. coli is of public health concern, and animals may be reservoirs, and they produce two potent cytotoxins (Stx1,Stx2), which inhibit protein synthesis (BENTANCOR et al., 2012).

Rising numbers of carbapenem resistant and ESBL-producing E. coli in foodproducing and companion animals (CARATTOLI, 2008; SMET et al., 2010; GHATAK et al., 2013; PRUTHVISHREE et al., 2017) may spread into the environment and also to humans. Companion animals have become more similar to family members and they share intimate contact with their owners, which can result in transmission cycles of multidrug resistant bacteria (MDR), as it is known that the microbiota of pets and their owners can be very similar (EWERS et al., 2011; WALTHER et al., 2012; JOHNSON et al., 2008). Increasing infections with antibacterial resistant bacteria are also accompanied by a decrease in the efficacy of treatment (ALANIS, 2005; STOYCHEVA and MURDJEVA, 2006; WALSH and FANNING, 2008; AJIBOYE et al., 2009). The present study reports the molecular characterization of a XDR E. coli harboring blaNDM1 gene.

\section{Materials and methods}

Sample collection and Isolation of E. coli. A male Labrador dog aged 3 years was presented to the referral veterinary hospital, Indian Veterinary Research Institute, Izatnagar, Bareilly, India with loss of appetite, scrotal edema and fever. The scrotal fluid was collected aseptically and processed for bacteriological analysis and biochemical characterization (QUINN et al., 1994). 
B. S. Pruthvishree et al.: Molecular characterization of extensively drug resistant (XDR) Escherichia coli isolated from a male dog

Phenotypic screening for carbapenem resistance and metallo betalactamase and extended spectrum and class $C$ beta-lactamase production. The strains (Accession No: KT853018, KR296661, KX090926 and KT593874) were collected from the repository maintained by the Division of Epidemiology, Indian Veterinary Research Institute, Izatnagar, to serve as reference strains. The biochemically confirmed $E$. coli isolate was screened for antibiotic susceptibility patterns with amikacin $(30 \mu \mathrm{g})$, amoxicillin $(10 \mu \mathrm{g})$, amoxicillin/clavulanic acid $(20 / 10 \mu \mathrm{g})$, aztreonam $(30 \mu \mathrm{g})$, cefoxitin $(30 \mu \mathrm{g})$, cefixime $(5$ $\mu \mathrm{g})$, cefpodoxime $(10 \mu \mathrm{g})$, cefotaxime/clavulanic acid $(30 / 10 \mu \mathrm{g})$, cephalexine $(30 \mu \mathrm{g})$, ceftrioxone $(30 \mu \mathrm{g})$, ceftazidime $(30 \mu \mathrm{g})$ ceftazidime/clavulanic acid $(30 / 10 \mu \mathrm{g})$, cefipime (30 $\mu \mathrm{g})$, cefadroxil, $(30 \mu \mathrm{g})$, ceftriaxone $(30 \mu \mathrm{g})$, cefotaxime $(30 \mu \mathrm{g})$, cefoperazone $(75 \mu \mathrm{g})$, cefepime-tazobactam $(80 / 10 \mu \mathrm{g})$, colisitin $(10 \mu \mathrm{g})$, chloramphenicol $(30 \mu \mathrm{g})$, ciprofloxacin $(5 \mu \mathrm{g})$, co-trimoxazole $(1.25 / 23.75 \mu \mathrm{g})$, ertapenem $(10 \mu \mathrm{g})$, fosfomycin $(200 \mu \mathrm{g})$, gatifloxacin $(5 \mu \mathrm{g})$, imipenem $(10 \mu \mathrm{g})$, meropenem $(10 \mu \mathrm{g})$, pipercillin $(100 \mu \mathrm{g})$, tetracycline $(30 \mu \mathrm{g})$, nitrofurantoin $(300 \mu \mathrm{g})$, gentamicin $(10 \mu \mathrm{g})$, triple sulpha $(0.25 \mu \mathrm{g})$, ofloxacin $(5 \mu \mathrm{g})$, norfloxacin $(10 \mu \mathrm{g})$, piperacillin-tazobactam $(100 / 10 \mu \mathrm{g})$, polymyxin $\mathrm{B}$ $(300 \mathrm{U})$, tobramycin $(10 \mu \mathrm{g})$, vancomycin $(5 \mu \mathrm{g})$, tigecycline $(15 \mu \mathrm{g})$,$) and moxalactam$ $(30 \mu \mathrm{g})$. The Clinical and Laboratory Standard Institute (CLSI, 2015) breakpoints were used for inference of antibacterial susceptibility pattern.

The isolate was also assayed for carbapenem susceptibility and ESBL production. Metallo beta-lactamase production (MBL) detection was performed using meropenem $(10 \mu \mathrm{g})$, imipenem $(10 \mu \mathrm{g})$ and ertapenem $(10 \mu \mathrm{g})$ along with metal ion chelator Ethylene diamine tetra acetic acid (EDTA) (1900 mg) disks for the Double disk synergy test (DDST) as mentioned by GALANI et al. (2008). A keyhole reaction, i.e. any synergistic inhibition between the carbapenem drug and EDTA was tentatively assumed for the metallo-beta lactamase producer. The minimum inhibitory concentration (MIC) for meropenem and colistin was determined using an Etest strip (HiMedia, India). For phenotypic identification of ESBL producers the combination disc method was used (ANDREWS, 2012) with cefotaxime, ceftazidime, with and without clavulanic acid. The triple ESBL, ESBL \& AmpC detection Ezy MIC Strip (\#cat EM079, EM081; HiMedia, India) was used to phenotypically confirm the extended spectrum and class $\mathrm{C}$ beta-lactamase production. The minimum inhibitory concentration (MIC) of cefotaxime, cefepime, ceftazidime, imipenem, meropenem, ertapenem and colistin was determined by Estrips (HiMedia, India).

Molecular detection of antimicrobial resistance and virulence genes. The genomic DNA was extracted by QIAamp DNA Mini Kit (Qiagen, India). All the PCR reactions were carried out in 96 well thermal cyclers (MJ Research PTC-200, Peltier Thermal Cycler, USA). The details of primers and PCR conditions used for major carbapenemase genes, ESBL producing genes, AmpC and virulence genes for Shiga toxin producing E. coli (STEC; Stx 1 and Stx2), enteropathogenic E. coli (EPEC: eaeA), enterohemolysin (hlyA) 
B. S. Pruthvishree et al.: Molecular characterization of extensively drug resistant (XDR) Escherichia coli isolated from a male dog

\begin{tabular}{|c|c|c|c|c|c|c|c|c|c|c|c|c|c|c|}
\hline 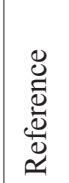 & 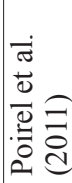 & 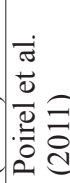 & 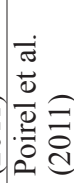 & 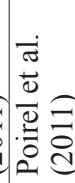 & 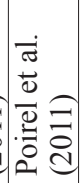 & 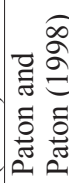 & 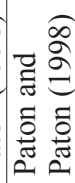 & 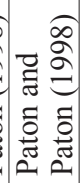 & 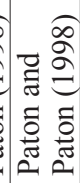 & 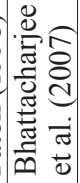 & 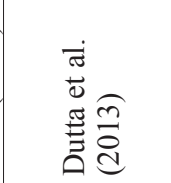 & 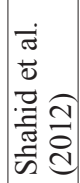 & 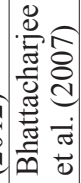 & 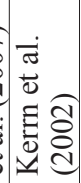 \\
\hline 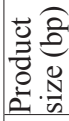 & तै & 욜 & $\stackrel{\infty}{\stackrel{\infty}{\sim}}$ & $\overrightarrow{\widetilde{\sigma}}$ & $\stackrel{\infty}{2}$ & $\infty$ & $\stackrel{n}{n}$ & 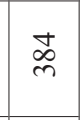 & $\underset{n}{n}$ & $\hat{\infty}$ & i⿱ & $\overline{6}$ & ๙ิ & $\stackrel{m}{\sim}$ \\
\hline 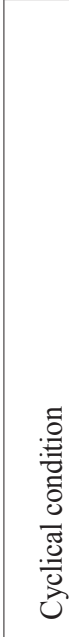 & 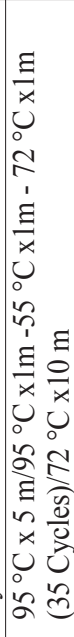 & 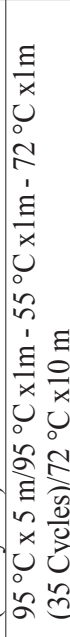 & 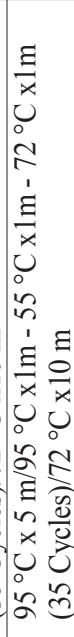 & 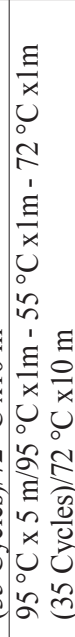 & 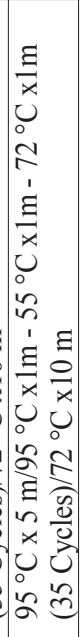 & 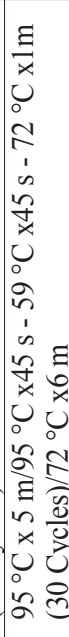 & 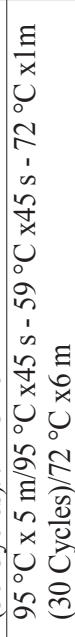 & 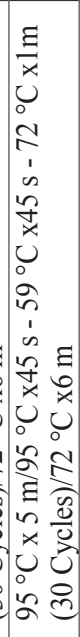 & 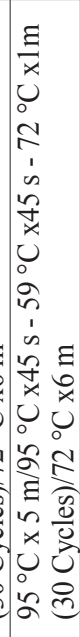 & 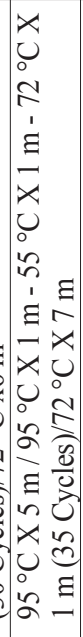 & 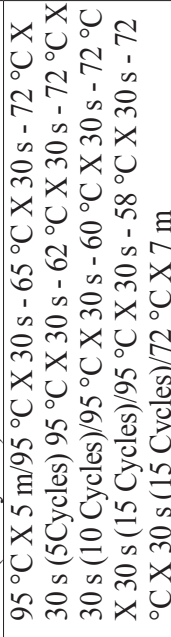 & 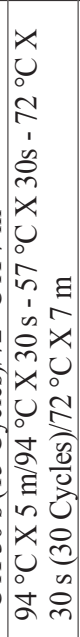 & 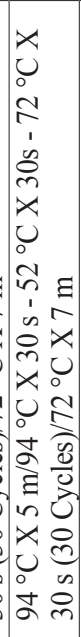 & 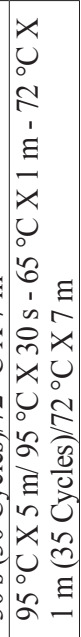 \\
\hline 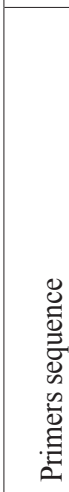 & 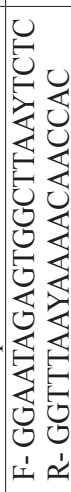 & 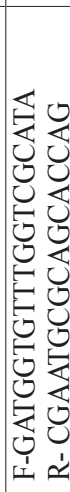 & 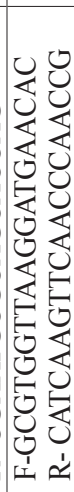 & 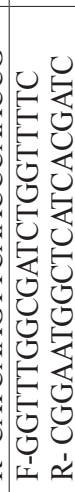 & 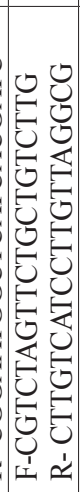 & 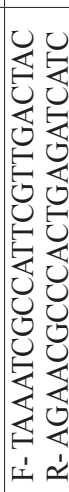 & 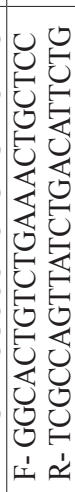 & 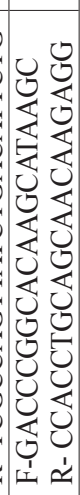 & 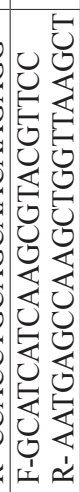 & 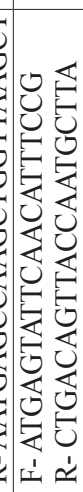 & 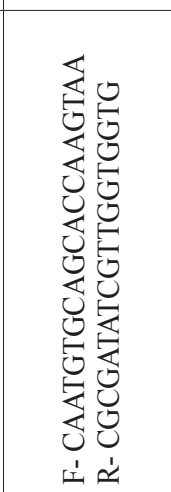 & 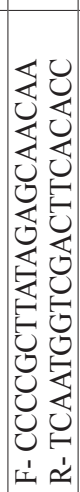 & 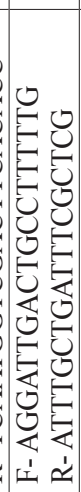 & 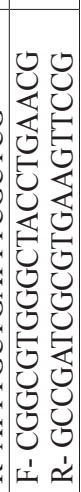 \\
\hline : & 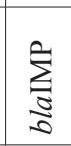 & $\sum_{\frac{1}{0}}^{\infty}$ & 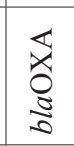 & $\sum_{\substack{0 \\
0}}$ & $\begin{array}{l}0 \\
\frac{1}{3} \\
0\end{array}$ & $\bar{\xi}$ & है & $\mathbb{\Xi}$ & $\underset{\Sigma}{\stackrel{\Xi}{2}}$ & $\frac{\sum_{1 \pm 1}}{\frac{5}{0}}$ & $\begin{array}{l}\sum_{\substack{x \\
0}} \\
0\end{array}$ & 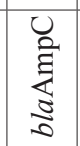 & 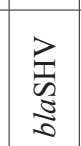 & 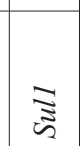 \\
\hline$\dot{z}$ & - & $N$ & $m$ & ナ & in & 0 & $r$ & $\infty$ & $a$ & 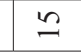 & 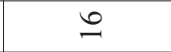 & $\beth$ & $\stackrel{\infty}{-1}$ & 2 \\
\hline
\end{tabular}


B. S. Pruthvishree et al.: Molecular characterization of extensively drug resistant (XDR) Escherichia coli isolated from a male dog

are listed in Table 1. The amplified products were visualized by a gel documentation system (UVP, UK) after electrophoresis in 1.5\% (w/v) agarose gel containing ethidium bromide $(0.5 \mu \mathrm{g} / \mathrm{mL}$, Loba Chemie, India).

Cloning and sequencing. Amplified positive PCR products were purified using a gel purification kit (Qiagen, India) and cloned in a p-Drive cloning vector (Qiagen, India). The plasmids containing the expected insert were sequenced using commercial sequencing services (Eurofins Ltd, Bangalore) for further purification and sequencing by the Sanger dideoxy method. After sequencing, homology searches were made using the BLAST algorithm available at http://blast.ncbi.nlm.nih. gov/Blast.cgi.

\section{Results}

The bacteriological analysis of scrotal fluid yielded an E. coli isolate and on phenotypic antimicrobial screening the isolate was found to be extensively drug resistant, of extended spectrum, class $\mathrm{C}$ and a metallo betalactamase (MBL) producer. The isolate was resistant to all the antimicrobial agents screened except tigecycline. The MIC of the different antibiotics are given in Table 2.

Table 2. Minimum inhibitory concentration, virulence and antibiotic resistance markers of $E$. coli isolate

\begin{tabular}{|c|c|c|c|c|c|c|c|c|c|c|}
\hline & \multicolumn{9}{|c|}{ Minimum Inhibitory Concentration $(\mu \mathrm{g} / \mathrm{mL})$} & Virulence \\
Isolate & CTX & CPM & CAZ & IMP & MRP & ETP & CL & $\begin{array}{l}\text { Antibiotic } \\
\text { resistance } \\
\text { markers }\end{array}$ & $\begin{array}{c}\text { GenBank } \\
\text { Accession } \\
\text { number }\end{array}$ \\
\hline $\begin{array}{l}\text { 7897P } \\
\text { E. coli }\end{array}$ & $>128$ & $>64$ & $>64$ & $>256$ & $>256$ & $>32$ & $>8$ & Stx2 & $\begin{array}{l}\text { blaNDM, } \\
\text { blaCTX-M, } \\
\text { blaAmpC, } \\
\text { blaTEM, } \\
\text { sull }\end{array}$ & KX158451 \\
KX090926 \\
KX158450
\end{tabular}

(CTX-cefotaxime; CPM- cefepime; CAZ-ceftazidime; IMP-imipenem; MRP- meropenem; ETP-ertapenem; CL-colistin)

On phenotypic MBL screening, the isolate showed a keyhole reaction between EDTA and meropenem. On MBL Estrip the ratio between meropenem MIC and meropenem with EDTA MIC was more than 8, which indicated the isolate as a potential MBL producer. The meropenem MIC of the isolate was more than $256 \mu \mathrm{g} / \mathrm{mL}$ and meropenem with EDTA MIC was $64 \mu \mathrm{g} / \mathrm{mL}$. The combined disc method showed the difference in zone of inhibition between cefotaxime, ceftazidime, with and without clavulanic acid, was more than $8 \mathrm{~mm}$, indicating ESBL producing E. coli. The ESBL \& AmpC detection Ezy MIC Strip showed the ratio between MIX+ (ceftazidime, cefotaxime \& cefepime with clavulanic acid) and MIX- (ceftazidime, cefotaxime \& cefepime) was more than 8 , indicating the isolate as a potential ESBL and AmpC producer. 
Molecular detection and sequence analysis revealed the isolate was positive for betalactamase genes blaTEM (Accession No: KX158451) blaCTX-M, blaAmpC (Accession No: KX158450), the carbapenemases gene blaNDM1 (Accession No: KX090926) and the gene for sulphonamide resistance sul1. On blast analysis (http://blast.ncbi.nlm.nih. gov/Blast.cgi) the dog E. coli isolate blaTEM, blaAmpC and blaNDM1 sequences had 100 per cent homology with blaTEM, blaAmpc, blaNDM1 sequences of bacterial isolates from humans and food animals.

\section{Discussion}

In general, ESBL producing and carbapenem resistant bacteria screening is limited to humans and the hospital environment, although recent reports suggest the emergence of such resistant pathogens in livestock, and companion and food animals (GHATAK et al., 2013; PRUTHVISHREE et al., 2017). There is an urgent need for routine screening for extended spectrum beta-lactamase producing and carbapenemase resistant bacteria in animals, since these mechanisms of resistance are transferable and are of public health significance. The companion animals' role has become more similar to that of family members, and they share intimate contact with their owners, which can result in transmission cycles of multi-drug resistant bacteria, as it is known that the microbiota of pets and their owners can be very similar (JOHNSON et al., 2008; EWERS et al., 2011; SONG et al., 2013; WALTHER et al., 2012).

STOLLE et al. (2013) studied carbapenemase producing Escherichia coli in dogs harbouring blaCTXM-1, blaOXA-2 and blaTEM-1 genes. YOUSFI et al. (2015) reported NDM-5 producing E. coli in a three-year-old German shepherd dog. HARADA et al. (2012) screened fecal samples of apparently healthy pups below two months of age from Japanese kennels, with no history of antimicrobial use, and they were found to harbor MDR E. coli isolates, including ESBL producers. The transmission of MDR pathogenic $E$. coli between companion animals and humans has been documented by a few studies (EWERS et al., 2010; PLATELL, et al. 2011).

RZEWUSKA et al. (2015) studied the frequency of MDR E. coli in dogs and cats in Poland and the prevalence of MDR was $66.8 \%$ in the isolates studied. Cats and dogs represent potential sources of the spread of antimicrobial resistance, due to the extensive use of antimicrobial agents in these animals and their close contact with humans, and some studies indicate a possible association between antimicrobial use and the emergence of antimicrobial resistance in pets (GUARDABASSI et al., 2004). In the present study, the SETC harboured blaCTXM, blaTEM, blaAmpC, blaNDM and sul1 genes. BOERLIN et al. (2005) observed a high correlation of antimicrobial resistance and virulence genes of E. coli isolates from swine. 
B. S. Pruthvishree et al.: Molecular characterization of extensively drug resistant (XDR) Escherichia coli isolated from a male dog

The emergence of XDR, carbapenem resistant and ESBL producing E. coli reflects the abundant use of broad-spectrum antimicrobials in veterinary care and human health. Household pets can be reservoirs of bacterial species and resistance genes of clinical importance in humans (SANCHEZ et al., 2002; GUARDABASSI et al., 2004). Carbapenem antibiotics are not licensed for veterinary use anywhere in world but, in contrast, the usage of carbapenems is increasing in humans (ASHIRU-OREDOPE et al., 2012). The presence of carbapenem resistant $E$. coli in the dog of the present study might be from humans or the contaminated environment. Carbapenem resistant, ESBL producing and MDR E. coli in companion animals is an important cause of concern in human medicine due to the fact that carbapenems are vital for the effective therapy of community-acquired and healthcare-associated infections caused by ESBL producing bacteria. Resistance to this class of antibiotic compromises the therapeutic options for patients by leaving only a few or in some cases no other antimicrobials available for effective treatment. To the best of our knowledge, this is the first report of blaNDM1 isolated from a dog in India.

\section{Conclusion}

The isolation of extensively drug resistant, extended spectrum, class $\mathrm{C}$ betalactamases and blaNDM-1 carbapenemase producing E. coli from a dog is of great public health concern and there is a great possibility of spread of these genes to other pathogens. Therefore preventive measures are needed to combat the rise of antimicrobial resistant pathogens in human and animal populations.

\section{Acknowledgements}

The authors thank The Director, IVRI, for providing the facilities to carry out the research work.

\section{Conflicts of interest}

The authors declare that they have no conflict of interest.

\section{References}

ANDREWS, J. (2012): Detection of extended-spectrum beta-lactamases (ESBLs) in E. coli and Klebsiella species. Brit. Soc. Antimicrob. Chemother., http://bsac.org.uk/wp-content/ uploads/2012/02/Ecoliklebsiella.pdf.

ALANIS, A. J. (2005): Resistance to antibiotics: are we in the post-antibiotic era? Arch. Med. Res. $36,697-705$.

AJIBOYE, R. M., O. D. SOlBERG, B. M. LEE, E. RAPHAEL, C. DEBROY, L. W. RILEY (2009): Global spread of mobile antimicrobial drug resistance determinants in human and animal Escherichia coli and Salmonella strains causing community-acquired infections. Clin. Infect. Dis. 49, 365-371. 
B. S. Pruthvishree et al.: Molecular characterization of extensively drug resistant (XDR) Escherichia coli isolated from a male dog

ASHIRU-OREDOPE, D., M. SHARLAND, E. CHARANI, C. MCNULTY, J. COOKE (2012): Improving the quality of antibiotic prescribing in the NHS by developing a new Antimicrobial stewardship programme: Start Smart-Then Focus. Antimicrob. Chemother. 67 (Suppl. 1), i51-i63.

BENTANCOR, A., M. V. RUMI, C. CARBONARI, E. GERHARDT, M. LARZABAL, D. A. VILTE, V. PISTONE-CREYDT, I. CHINEN, C. IBARRA, A. CATALDI, E. C. MERCADO (2012): Profile of Shiga toxin-producing Escherichia coli strains isolated from dogs and cats and genetic relationships with isolates from cattle, meat and humans. Vet. Microbiol. 156, 336-342.

BHATTACHARJEE, A., M. R SEN, S. ANUPURBA, P. PRAKASH, G. NATH (2007): Detection of OXA-2 group extended spectrum beta-lactamase producing clinical isolates of Escherichia coli from India. J. Antimicrob. Chemother. 60, 703-704.

BOERLIN, P., R. TRAVIS, C. L. GYLES, R. REID-SMITH, N. J. H. LIM, V. NICHOLSON, M. ARCHAMBAULT (2005): Antimicrobial resistance and virulence genes of Escherichia coli isolates from swine in Ontario. Appl. Environ. Microbiol. 71, 6753-6761.

CARATTOLI, A. (2008): Animal reservoirs for extended spectrum $\beta$-lactamase producers. Clin. Microbiol. Infect. 14, 117-123.

CLSI (2015): Performance standards for antimicrobial susceptibility testing, Clinical and Laboratory Standard Institute. CLSI document, Wayne, PA, pp. M100-S25.

DUTTA, T. K., I. WARJRI, P. ROYCHOUDHURY, H. LALZAMPUIA, I. SAMANTA, S. N. JOARDAR, S. BANDYOPADHYAY, R. CHANDRA (2013): Extended spectrum betalactamase producing Escherichia coli isolate possessing the Shiga toxin gene (Stx 1$)$ belonging to the O64 serogroup associated with human disease in India. J. Clin. Microbiol. 51, 2008-2009.

EWERS, C., M. GROBBEL, I. STAMM, P. A. KOPP, I. DIEHL, T. SEMMLER, S. GUENTHER (2010): Emergence of human pandemic O25: H4-ST131 CTX-M-15 extended spectrum $\beta$-lactamase producing Escherichia coli among companion animals. J. Antimicrob. Chemother. 65, 651-660.

EWERS, C., M. GROBBEL, A. BETHE, L. H. WIELER, S. GUENTHER (2011): Extendedspectrum beta-lactamases-producing gram-negative bacteria in companion animals: action is clearly warranted. Berl. Münch.Tierärztl. Wochenschr. 124, 94-101.

FALAGAS, M. E., D. E. KARAGEORGOPOULOS (2008): Pandrug resistance (PDR), extensive drug resistance (XDR), and multidrug resistance (MDR) among Gram-negative bacilli: need for international harmonization in terminology. Clin. Infect. Dis. 46, 1121-1122.

GALANI, I., P. D REKATSINA, D. HATZAKI, D. PlACHOURAS, M. SOULI, H. GIAMARELLOU (2008): Evaluation of different laboratory tests for the detection of metallo$\beta$-lactamase production in Enterobacteriaceae. J. Antimicrob. Chemother. 61, 548-553.

GHATAK, S., A. SINGHA, A. SEN, C. GUHA, A. AHUJA, U. BHATTACHARJEE, S. DAS, N. R. PRADHAN, K. PURO, C. JANA, T. K. DEY (2013): Detection of New Delhi metallo beta-lactamase and extended spectrum beta-lactamase genes in Escherichia coli isolated from mastitic milk samples. Transbound. Emerg. Dis. 60, 385-389. 
B. S. Pruthvishree et al.: Molecular characterization of extensively drug resistant (XDR) Escherichia coli isolated from a male dog

GUARDABASSI, L., S. SCHWARZ, D. H. LLOYD (2004): Pet animals as reservoirs of antimicrobial-resistant bacteria Review. J. Antimicrob. Chemother. 54, 321-332.

JOHNSON, J. R., K. OWENS, A. GAJEWSKI, C. CLABOTS (2008): Escherichia coli colonization patterns among human household members and pets, with attention to acute urinary tract infection. J. Infect. Dis. 197, 218-224.

HARADA, K., A. NIINA, Y. NAKAI, Y. KATAOKA, T. TAKAHASHI (2012): Prevalence of antimicrobial resistance in relation to virulence genes and phylogenetic origins among urogenital Escherichia coli isolates from dogs and cats in Japan. Am. J. Vet. Res. 73, 409-417.

KERRN, M., T. KLEMMENSEN, N. FRIMODT-MOLLER, F. ESPERSEN (2002): Susceptibility of Danish Escherichia coli strains isolated from urinary tract infections and bacteraemia, and distribution of sul genes conferring sulphonamide resistance. J. Antimicrob. Chemother. 50, 513-516.

PATON, A. W., J. C. PATON (1998): Detection and characterization of Shiga toxigenic Escherichia coli by using multiplex PCR assays for Stx 1, Stx2, eaeA, Enterohemorrhagic E. coli hlyA, rfb O111, and rfb O157. J. Clin. Microbiol. 36, 598-602.

PlATElL, J. L., R. N. COBBOLD, J. R. JOHNSON, A. HEISIG, P. HEISIG, C. CLABOTS, D. J. TROTT (2011): Commonality among fluoroquinolone-resistant sequence type ST131 extraintestinal Escherichia coli isolates from humans and companion animals in Australia. Antimicrob. Agents Chemother. 55, 3782-3787.

POIREL, L., T. R. WALSH, V. CUVILLIER, P. NORDMANN (2011): Multiplex PCR for detection of acquired carbapenemase genes. Diagnostic Microbial. Infect. Dis. 70, 119-123.

PRUTHVISHREE, B. S., O. R. VINODH KUMAR, D. K. SINHA, Y. P. S. MALIK, Z. B. DUBAL, P. A. DESINGU, M. SHIVAKUMAR, K. NARAYANAN, B. R. SINGH (2017): Spatial molecular epidemiology of carbapenem-resistant and New Delhi metallo beta-lactamase (blaNDM) producing Escherichia coli in the piglets of organized farms in India. J. Appl. Microbiol. 122, pp. 1537-1546.

DOI: $10.1111 /$ jam. 13455

QUINN, P. J., M. E. CARTER, B. MARKEY, G. R. CARTER (1994): Clinical Veterinary Microbiology, (Quinn, P. J., M. E. Carter, B. K. Markey, G. R. Carter, Eds.). Wolfe-Mosby Publishing, London, United Kingdom.

RZEWUSKA, M., M. CZOPOWICZ, M. KIZERWETTER-SWIDA, D. CHROBAK, B. BŁASZCZAK, M. BINEK (2015): Multidrug resistance in Escherichia coli strains isolated from infections in dogs and cats in Poland (2007-2013). Scientific. World. J. 2015, 1-8.

SANCHEZ, S., M. M. STEVENSON, C. R. HUDSON, M. MAIER, T. BUFFINGTON, Q. DAM, J. J. MAURER (2002): Characterization of multidrug-resistant Escherichia coli isolates associated with nosocomial infections in dogs. J. Clin. Microbiol. 40, 3586-3595.

SHAHID, M., F. SOBIA, A. SINGH, H. M. KHAN (2012): Concurrent occurrence of blaAmpC families and blaCTX-M genogroups and association with mobile genetic elements ISEcp1, IS26, ISCR1, and sul1 type class 1 integrons in Escherichia coli and Klebsiella pneumoniae isolates originating from India. J. Clin. Microbiol. 50, 1779-1782. 
B. S. Pruthvishree et al.: Molecular characterization of extensively drug resistant (XDR) Escherichia coli isolated from a male dog

STOYCHEVA, M. V., M. A. MURDJEVA (2006): Antimicrobial therapy of salmonelloses-current state and perspectives. Folia Med. (Plovdiv) 48, 5-10.

SMET, A., A. MARTEL, D. PERSOONS, J. DEWULF, M. HEYNDRICKX, L. HERMAN, P. BUTAYE (2010): Broad-spectrum $\beta$-lactamases among Enterobacteriaceae of animal origin: molecular aspects, mobility and impact on public health. FEMS Microbiol. Rev. 34, 295-316.

SONG, S. J, C. LAUBER, E. K. COSTELLO, C. A. LOZUPONE, G. HUMPHREY, D. BERGLYONS, J. I. GORDON (2013): Cohabiting family members share microbiota with one another and with their dogs. Elife. 2, e00458.

STOLLE, I., E. PRENGER-BERNINGHOFF, I. STAMM, S. SCHEUFEN, E. HASSDENTEUFEL, S. GUENTHER, C. EWERS (2013): Emergence of OXA-48 carbapenemase-producing Escherichia coli and Klebsiella pneumoniae in dogs. J. Antimicrob. Chemother. 68, 2802-2808.

YOUSFI, M., A. MAIRI, S. BAKOUR, A. TOUATI, L. HASSISSEN, L. HADJADJ, J. M. ROLAIN (2015): First report of NDM-5-producing Escherichia coli ST1284 isolated from dog in Bejaia, Algeria. New Microbes New infect. 8, 17-18.

WALSH C., S. FANNING (2008): Antimicrobial resistance in foodborne pathogens-a cause for concern? Curr. Drug Targets 9, 808-815.

WALTHER, B., J. HERMES, C. CUNY, L. H. WIELER, S. VINCZE, Y. A. ELNAGA, A. JANSEN (2012): Sharing more than friendship-nasal colonization with coagulase-positive Staphylococci (CPS) and co-habitation aspects of dogs and their owners. PLoS One. 7 (4), e35197.

Received: 24 September 2016

Accepted: 8 May 2017

PRUTHVISHREE, B. S., O. R. VINODH KUMAR, M. SIVAKUMAR, S. TAMTA, R. SUNITHA, D. K. SINHA, B. R. SINGH: Molekularna karakterizacija iz psa izdvojenog izolata bakterije Escherichia coli koji proizvodi prošireni spektrum beta-laktamaza i New Delhi metalo-beta-laktamazu-1 (blaNDM1) - prikaz slučaja. Vet. arhiv 88, 139-148, 2018.

\section{SAŽETAK}

U radu se izvješćuje o molekularnoj karakterizaciji bakterije $E$. coli izdvojene iz skrotalne tekućine psa, iznimno otporne na antibiotike širokog spektra, koja proizvodi klasu C beta-laktamaza i NDM-1 karbapenemazu. Pas je bio u dobi od od tri godine. Izolat $E$. coli bio je osjetljiv samo na tigeciklin, a otporan na sve antibiotike primjenjivane u kliničkoj praksi. Minimalna inhibicijska koncentracija (MIC) za meropenem iznosila je 256, cefotaksim 128 i cefepim $64 \mu \mathrm{g} / \mathrm{mL}$. Pretragom genotipa lančanom reakcijom polimerazom izolat je bio pozitivan na gene blaNDM, blaCTX-M, blaAmpC, blaTEM i sull. Proizvodio je ESBL, AmpC i metalo-betalaktamazu. Molekularnom patotipizacijom dokazano je da posjeduje gen za shiga-toksin (Stx2). E. coli otporna na karbapenem, koja proizvodi beta-laktamaze širokog spektra, velika je prijetnja za javno zdravstvo s obzirom na to da postoji velika mogućnost prijenosa $E$. coli s genom za rezistenciju na ljude u bliskom dodiru s kućnim ljubimcima. Ovo je prvo izvješće o blaNDM1 dokazanom u psa u Indiji.

Ključne riječi: pas; NDM; ESBL; karbapenemaza; beta-laktamaza 